PREPARED IN COOPERATION WITH THE COMMONWEALTH OF MASSACHUSETTS

DEPARTMENT OF PUBLIC WORKS

\title{
AEROMAGNETIC MAP OF THE QUABBIN RESERVOIR QUADRANGLE FRANKLIN, WORCESTER, AND HAMPSHIRE COUNTIES, MASSACHUSETTS
}

\author{
GEOPHYSICAL INVESTIGATIONS \\ MAP GP-698
}

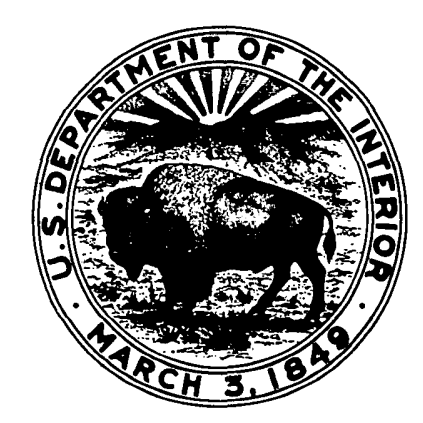

